\title{
The Torch Press: Addenda to a Checklist
}

\section{MIKE MADDIGAN}

The two-part checklist which follows is intended as a supplement to the Torch Press bibliography by Thomas L. Carney and Joyce Crawford published in the November 1974 issue of Books at Iowa. Part one furnishes addenda to the "limited editions" section of that earlier listing; part two is a wholly new category which attempts to record items of "significant Americana" that were printed at the Torch Press.

\section{Limited Editions}

Using the Carney-Crawford checklist as a point of departure and having examined the Torch Press holdings of relevant libraries in the Cedar Rapids-Iowa City area, I sought to augment the listing of limited editions by combing through such specialized publications as the "List of Books Privately Printed by William Keeney Bixby, 19031916 "; 1 Florence M. Power's "American Private Book Clubs"; ${ }^{2}$ the bibliographies of Rowfant Club publications compiled by Clark and by Schubert; ${ }^{3}$ the Catalog of Special and Private Presses recently issued by the New York Public Library; ${ }^{4}$ and files of the Step-Ladder, which I spot-checked at the Chicago Public Library. ${ }^{5}$

1 This list will be found on pages [319]-322 of Thomas Jefferson Correspondence Printed from the Originals in the Collection of William K. Bixby (Boston, 1916).

2 In Bulletin of Bibliography (September-December 1952), pp 216-220, and (January-April 1953), pp 233-236.

3 Henry Arthur Clark, A Bibliography of the Publications of the Rowfant Club (Cleveland, 1925); and Leland Schubert, A Bibliography of the Publications of the Rowfant Club, Part Two, 1925-1961 (Cleveland, 1962).

4 Catalog of Special and Private Presses in the Rare Book Division, The Research Libraries, The New York Public Library, 2 vols. (Boston, 1978).

5 The Bookfellows, perhaps, is the major open question. An examination of three annual volumes of the Step-Ladder showed that there was no systematic attempt, at least in the earlier years, at a bibliography. The Bookfellows needs a serious study, but on its own merit, rather than as an adjunct to Torch Press bibliography. 
The above searches provided names of some two hundred forty authors who were known to have had work printed at the Torch Press. All entries for these authors were then checked in the National Union Catalog of Pre-1956 Imprints, and scores of titles that suggested themselves as possible Torch Press publications were examined in area libraries or were examined for me by librarians in widely scattered libraries. In addition, inquiries were made of publishers for whom the Torch Press was known to have done printing, including the University of Minnesota Press, Columbia University Press, and, as noted later, the Arthur H. Clark Company. As expected, most of the entries in this section represent publications of the Bibliophile Society, the Rowfant Club, the Bookfellows, and Walter M. Hill. This listing is not restricted to limited editions, but includes limited issues in some cases where there was also an unrestricted trade edition. I believe this is consistent with the Carney and Crawford checklist. I have excluded most annuals, memoria, addresses, programs, official publications, advertising material, and periodical offprints.

1906

EARLY WESTERN TRAVELS, 1748-1846: VOLUME 25, comprising the series of original paintings by Charles Bodmer, to illustrate Maximilian, Prince of Wied's, Travels in the Interior of North America, 1832-1834, edited by Reuben Gold Thwaites. Cleveland: Arthur H. Clark Co. 81 plates, folding map; $52 \times 40 \mathrm{~cm}$; red cloth; 750 copies.

ROBERT HERRICK: PAGAN PRIEST by Clarence LaRue Madden. Cedar Rapids: The Torch Press. 63 p.; 13 x $8 \mathrm{~cm}$.; black boards, tan cloth spine; 200 copies.

\section{7}

AS I JOURNEY ON: POEMS IN VARIOUS MOODS, by William Curtis Wakefield. 28 p.; $25 \mathrm{~cm}$; wrapper; 500 copies.

THE ENGLISH SETTLEMENT IN THE ILLINOIS, Reprints of Three Rare Tracts on the Illinois Country, ... . edited by Edwin Erle Sparks. London and Cedar Rapids: The Museum Book Store and The Torch Press. 40, 36, 80 p.; $22 \times 14 \mathrm{~cm}$; blue cloth, gilt top; 250 copies on small paper, 10 copies on large paper.

\section{9}

SPEECH OF CHARLES DICKENS DELIVERED AT GORE HOUSE, KENSINGTON, MAY 10, 1851, printed from the original autograph manuscript. Boston: Exclusively for Members of the Bibliophile Society. 17 p.; 23 x $17 \mathrm{~cm}$.; blue wrappers; [500 copies?] 
FIRST AND EARLY AMERICAN EDITIONS OF THE WORKS OF CHARLES DICKENS, by William Glyde Wilkins. Cedar Rapids: Privately printed. 51 p.; $24 \times 15.5 \mathrm{~cm}$.; cloth-backed grey boards; 200 copies.

HISTORY OF THE GRAND LODGE OF IOWA, A.F. AND A.M., vol. I, by Joseph E. Morcombe. [n.p.] Grand Lodge of Iowa. 1,300 copies.

A MIDSUMMER MEMORY: AN ELEGY ON THE DEATH OF ARTHUR UPSON, by Richard Burton. Minneapolis: Edmund D. Brooke. 41 p.; 20.5 x 13 cm.; cloth-backed blue-grey boards; 500 copies.

\section{1}

THE ELOPEMENT OF PERCY BYSSHE SHELLEY AND MARY WOLLSTONECRAFT GODWIN AS NARRATED BY WILLIAM GODWIN, with commentary by H. Buxton Forman. [n.p.] Privately Printed. 24 p.; 24 x $17 \mathrm{~cm}$; light mustard buckram; 200 copies. ("Two hundred copies printed for Mr. William K. Bixby, for private distribution.”)

1912

A GENEALOGICAL HISTORY OF THE FRENCI AND ALLIED FAMILIES, by Mary Queal Beyer. Cedar Rapids: The Torch Press. 373 p.; 29 cm.; illus.; 200 copies.

1913

ABRAHAM LINCOLN: A POETICAL INTERPRETATION, by George William Bell. Cleveland: Privately printed for the author by the Arthur $\mathrm{H}$. Clark Co. 95 p.; 23.5 x 15.5 cm.; leather-backed grey boards; 125 copies.

BATTLE OF SPRING HILL, TENNESSEE, NOVEMBER 29, 1864, by John K. Shellenberger. Cleveland: The Arthur H. Clark Co. 49 p.; 24 cm.; illus; 125 copies.

HISTORY OF THE GRAND LODGE OF IOWA, A.F. AND A.M., vol. II, part 1, by William F. Cleveland. [n.p.] Grand Lodge of Iowa. 375 p.; $24 \mathrm{x}$ $16 \mathrm{~cm}$; blue cloth; illus.; 1,300 copies.

1914

THE THIRTEENTH YEAR BOOK, 1914. [Boston: The Bibliophile Society] 122 p.; 23 x 16.5 cm.; tan boards; 500 copies.

1915

THE CALL OF KANSAS, AND LATER VERSE, by Esther Clark Hill. [Cedar Rapids: The Torch Press] 66 p.; $20.5 \times 14$ cm.; brown cloth; 1,000 copies. (?1915: Year of publication is undetermined.) 
THE END OF THE PLAY, by William Makepeace Thackeray. New York: [Printed for Thomas Nast Fairbanks] 17 p.; $22 \times 15 \mathrm{~cm}$.; imitation vellumbacked purple boards; 200 copies.

THE FOURTEENTH YEAR BOOK, 1915. [Boston: The Bibliophile Society] 206 p.; $23.5 \times 16.5 \mathrm{~cm}$; cream-colored boards; 500 copies.

HISTORY OF THE GRAND LODGE OF IOWA, A.F. AND A.M., vol. II, part 2, by William F. Cleveland. [n.p.] Grand Lodge of Iowa. 424 p.; 24 x $16 \mathrm{~cm}$; blue cloth; illus.; 1,300 copies.

HOLOGRAPH LETTER OF CHARLES I, FORMERLY IN THE POSSESSION OF JOHN EVELYN. St. Louis: W. K. Bixby; 6 p.; 23.5 cm.; illus.; 200 copies.

LAURENCE STERNE'S LETTER TO THE REV. MR. BLAKE. St. Louis: W. K. Bixby; 6 p.; 23.5 cm.; cream-colored boards; illus.; 200 copies.

A RARE FIRST EDITION: BEING THE STORY OF JOAQUIN MILLER'S PACIFIC POEMS (1871) OF WHICH ONLY TWO COPIES ARE AT PRESENT KNOWN, edited by Walter M. Hill. Chicago: Walter M. Hill. 10 leaves; 16.5 x $11 \mathrm{~cm}$; gray wrappers; 100 copies.

REPORT OF THE PUBLIC DINNER GIVEN TO CHARLES DICKENS AT THE WATERLOO ROOMS, EDINBURGH ON FRIDAY JUNE 25, 1841. [Cedar Rapids]; Privately printed for William Glyde Wilkins, 58 p; $24.5 \times 16.5 \mathrm{~cm}$.; blue paper wrapper; 63 copies.

SOME EDGAR ALLAN POE LETTERS. Printed for private distribution only from originals in the collection of W. K. Bixby. St. Louis: William K. Bixby. 26 p.; $23 \times 16$ cm.; cream boards; illus.; 200 copies.

STONEWALL JACKSON'S WAY, by John Williamson Palmer. St. Louis: W. K. Bixby. 7 p.; 23.5 x $16.5 \mathrm{~cm}$; cream-colored wrapper; 200 copies.

1916

THE BATTLE OF FRANKLIN TENNESSEE, NOVEMBER 30, 1864, by John K. Shellenberger. Cleveland: The Arthur H. Clark Co. 42 p.; 24 cm.; 125 copies.

EARLY YEARS ON THE WESTERN RESERVE, by George C. Wing. Cleveland: The Arthur H. Clark Co. 142 p.; 24 cm.; reddish-brown cloth; illus.; 150 copies. (Howes W562.)

THE FIFTEENTH YEAR BOOK, 1916. [Boston: The Bibliophile Society] 184 p.; $23 \times 16.5 \mathrm{~cm}$; cream-colored boards; 500 copies.

POEMS BY ROBERT LOUIS STEVENSON HITHERTO UNPUBLISHED, WITH INTRODUCTION AND NOTES BY GEORGE S. 
HELLMAN. Boston: The Bibliophile Society. 2 vols.; 232, 216 p.; $26.5 \mathrm{x}$ $19 \mathrm{~cm}$; 先 vellum, green cloth sides; 484 copies.

ROBERT LOUIS STEVENSON: CATALOGUE OF A REMARKABLE COLLECTION OF FIRST EDITIONS . . . by Walter M. Hill. (Catalog Number 64.) Chicago: Walter M. Hill. 88 p.; 24 x $16 \mathrm{~cm}$; marbled boards; illus.; 50 large-paper copies on Italian handmade laid paper.

TO MARY IN HEAVEN, by Robert Burns. Boston: The Bibliophile Society. 26 p.; 24 x $15.6 \mathrm{~cm}$.; cream boards; 500 copies.

1917

POEMS BY ROBERT LOUIS STEVENSON WITH INTRODUCTION AND NOTES BY GEORGE S. HELLMAN. Minneapolis: Privately printed for Edmund D. Brooks. 27 p.; $23 \times 16.5 \mathrm{~cm}$; gray paper over boards, cloth spine; 50 copies.

THE [ROWFANT CLUB] YEAR BOOK FOR 1915. [Cleveland: The Rowfant Club] 88 p.; $19 \times 12.5$ cm.; blue cloth-backed boards; slipcase; illus.; 125 copies.

THE [ROWFANT CLUB] YEAR BOOK FOR 1916. [Cleveland: The Rowfant Club] 76 p.; 19 × $12.5 \mathrm{~cm}$; blue cloth-backed boards; slipcase; illus.; 125 copies.

THE [ROWFANT CLUB] YEAR BOOK FOR 1917. [Cleveland: The Rowfant Club] 81 p.; 19 x $12.5 \mathrm{~cm}$.; blue cloth-backed boards; slipcase; illus.; 125 copies.

THE SIXTEENTH YEAR BOOK, 1917. [Boston: The Bibliophile Society] 136 p.; 23.5 x $16.5 \mathrm{~cm}$; cream-colored boards; 500 copies.

1918

ARTHUR MACHEN, A NOVELIST OF ECSTASY AND SIN, by Vincent Starrett. Chicago: Walter M. Hill. 35 p.; 18.5 x 12 cm.; blue cloth-backed boards; 250 copies.

THE BATTLE OF LAKE ERIE; A COLLECTION OF DOCUMENTS CHIEFLY BY COMMODORE PERRY, . . . edited by Charles Oscar Paulin. Cleveland: The Rowfant Club. 224 p.; $24.5 \mathrm{~cm}$; blue linen-backed boards; illus.; 150 copies.

PROCEEDINGS OF THE CONFERENCE OF GRAND MASTERS AND REPRESENTATIVES. Cedar Rapids: [Grand Lodge of Iowa] 397 p.; 24.5 $x 16.5 \mathrm{~cm}$.; blue cloth; illus.; 750 copies.

THE SEVENTEENTH YEAR BOOK, 1918. [Boston: The Bibliophile Society] 198 p.; $23 \times 16.5 \mathrm{~cm}$; tan boards, imitation-vellum spine and corners; 500 copies. 
THE EIGHTEENTH YEAR BOOK, 1919. [Boston: The Bibliophile Society] 164 p.; 23 x $16 \mathrm{~cm}$.; cream-colored boards; 500 copies.

HISTORICAL MEMOIR OF THE BEGINNINGS OF CALIFORNIA, SONORA, AND ARIZONA, ... by Father Eusebio F. Kino. Cleveland: The Arthur H. Clark Co. 2 vols.: 379,329 p.; 24.5 x 17 cm.; burgundy red cloth; illus.; 750 copies.

IN PRAISE OF STEVENSON; AN ANTHOLOGY, edited by Vincent Starrett. Chicago: The Bookfellows. 142 p.; 20.5 x 14 cm.; dark green cloth-backed boards; 325 copies.

THE LATE MR. KATTERBY, by Maurice Lazar. Chicago: Walter M. Hill. 67 p.; 20.5 x $12 \mathrm{~cm}$.; blue boards; 200 copies.

THE [ROWFANT CLUB] YEAR BOOK FOR 1918. [Cleveland: The Rowfant Club] 79 p.; 19 × 12.5 cm.; blue cloth-backed boards; slipcase; illus.; 125 copies.

AMBROSE BIERCE, by Vincent Starrett. Chicago: Walter M. Hill. 50 p.; grey cloth-backed boards; 20 x $14 \mathrm{~cm}$.; 250 copies.

THE JESTS OF HIEROCLES AND PHILAGRIUS NEWLY TRANSLATED FROM THE GREEK BY CHARLES CLINCH BUBB. Cleveland: The Rowfant Club. 112 p.; $19 \times 12.5$ cm.; blue linen-backed boards; 125 copies.

LYRICS, by Laura Blackburn [i.e., Charles Granger Blanden] Chicago: The Bookfellows. 62 p.; 19.5 × 12.5 cm.; brown cloth-backed boards; 300 copies.

THE [ROWFANT CLUB] YEAR BOOK FOR 1919. [Cleveland: The Rowfant Clubl 78 p.; 19 × 12 cm.; blue cloth-backed boards; slipcase; illus.; 125 copies.

THE UNITED STATES: A CATALOGUE OF BOOKS RELATING TO THE HISTORY OF ITS VARIOUS STATES, COUNTIES AND CITIES . . . Cleveland: The Arthur H. Clark Co. 321 p.; $24 \times 16 \mathrm{~cm}$.; green cloth; "one hundred and fifty copies were specially printed on antique paper and bound in cloth."

WILLIAM DE MORGAN, A POST-VICTORIAN REALIST, by Flora Warren Seymour. Chicago: The Bookfellows. 72 p.; $19.5 \times 12 \mathrm{~cm}$; brown cloth-backed boards; 400 copies.

THE BOOK COLLECTOR'S GUIDE: A PRACTICAL HANDBOOK OF BRITISH AND AMERICAN BIBLIOGRAPHY, by Seymour de Ricci. Phil- 
adelphia [and] New York: The Rosenbach Company. 649 p.; 23 x 15.5 cm.; green cloth; 1,100 copies (100 on Japan paper).

CANDLES IN THE SUN, by William Griffith. Chicago: The Bookfellows. 90 p.; $19.5 \mathrm{~cm}$.; 450 copies.

THE EARLY YEARS OF THE SATURDAY CLUB, by Thomas Lynn Johnson. Cleveland: The Rowfant Club. 72 p.; 19.5 x 13 cm.; grey wrappers; illus.; 125 copies.

IN GOSSAMER GREY by Oscar Williams. Chicago: The Bookfellows. 16 p.; 21 x 14 cm.; beige wrappers; 750 copies.

JAPANESE COLLECTORS AND WHAT THEY COLLECT, by Frederick Starr. Chicago: The Bookfellows. 25 p.; 20.5 x 14 cm.; brown wrappers; 750 copies.

JOSEPH HERGESHEIMER: AN ESSAY IN INTERPRETATION, by James Branch Cabell. Chicago: The Bookfellows. 27 p.; 20.5 x 14 cm.; wrappers. 1,000 small-paper and 99 tall-paper copies.

THE LOST ORACLES: A MASQUE, by James Westfall Thompson. Chicago: Walter M. Hill. 143 p.; 16 x 24 cm.; parchment-backed boards; 500 copies.

POEMS BY ROBERT LOUIS STEVENSON HITHERTO UNPUBLISHED, WITH INTRODUCTION AND NOTES BY GEORGE S. HELLMAN AND WILLIAM P. TRENT. Boston: The Bibliophile Society. 142 p.; $22.5 \times 18 \mathrm{~cm}$; 尔 vellum, tan cloth sides; slipcased; 450 copies.

ROBERT LOUIS STEVENSON; HITHERTO UNPUBLISHED PROSE WRITINGS, edited by Henry $\mathrm{H}$. Harper. Boston: The Bibliophile Society. 195 p.; 22.5 x $18 \mathrm{~cm}$; red paper over boards, white paper spine; slipcased; 450 copies.

THE [ROWFANT CLUB] YEAR BOOK FOR 1920. [Cleveland: The Rowfant Club] 111 p.; 19 × $12 \mathrm{~cm}$; blue cloth-backed boards; slipcase; illus.; 125 copies.

WHEN THE DEVIL WAS WELL: HITHERTO UNPUBLISHED STORY, by Robert Louis Stevenson, with introduction by William $P$. Trent. Boston: The Bibliophile Society. 127 p.; $22.5 \times 18 \mathrm{~cm}$.; green paper over boards, white-paper spine; slipcased; 450 copies.

1922

BOOKPLATES FOR BEGINNERS, by Alfred Fowler. Kansas City: Alfred Fowler. 48 p.; $31.5 \times 24$ cm.; paper-covered boards; illus.; 500 copies.

CONTRIBUTIONS TOWARDS A BIBLIOGRAPHY OF GULLIVER'S TRAVELS, . . . by Lucius L. Hubbard. Chicago: Walter M. Hill. 189 p.; $21 \times 14 \mathrm{~cm}$; blue cloth; illus.; 200 copies. 
THE [ROWFANT CLUB] YEAR BOOK FOR 1921. [Cleveland: The Rowfant Club] 101 p.; 19 × 12 cm.; blue cloth-backed boards; slipcase; illus; 125 copies.

THE [ROWFANT CLUB] YEAR BOOK FOR 1922. [Cleveland: The Rowfant Club] 83 p.; 19 × 12 cm.; blue cloth-backed boards; slipcase; illus.; 125 copies.

THE SINGING PLACE AND OTHER POEMS, by Lily A. Long. Chicago: The Bookfellows. 63 p.; 19.5 x 12 cm.; tan cloth-backed boards; 500 copies.

THE BOOKPLATE ANNUAL FOR 1923, edited by Alfred Fowler. Kansas City: Alfred Fowler. 47 p.; $33 \times 25$ cm.; cream paper boards; illus.; 500 copies.

CAPTAIN CHARLES MORRIS; THE BARD OF THE SUBLIME SOCIETY OF BEEF STEAKS, by Richard Dexter. Cleveland: The Rowfant Club. 172 p.; 20 x 15.5 cm.; grey wrappers; illus.; 130 copies.

THE JOURNAL OF JOHN WORK, A CHIEF-TRADER OF THE HUDSON'S BAY CO. DURING HIS EXPEDITION FROM VANCOUVER TO THE FLATHEADS AND BLACKFEET OF THE PACIFIC NORTHWEST, edited ... by William S. Lewis and Paul C. Phillips. Cleveland: The Arthur H. Clark Co. 209 p.; 23 x 15 cm.; green cloth; illus.; 1,000 copies. (Smith 11212.)

MY WOODS, by Samuel Harper. [Chicago] The Bookfellows. 161 p.; 20.5 x $14.5 \mathrm{~cm}$.; green cloth-backed boards; 700 copies.

UNTRODDEN FIELDS IN HISTORY AND LITERATURE AND OTHER ESSAYS BY FRANKLIN HARVEY HEAD, edited by George Brooks Shepard. Cleveland: The Rowfant Club. 2 vols.: 208, 272 p.; $20 \mathrm{x}$ $14.5 \mathrm{~cm}$; ${ }^{*}$ calf and grey boards; 165 copies.

THE BOOKPLATE ANNUAL FOR 1924, edited by Alfred Fowler. Kansas City: Alfred Fowler. 58 p.; 33 x 25 cm.; blue paper boards; illus; 500 copies.

PENNY WISE [VERSES] by Richard Kirk. Chicago: The Bookfellows. 41 p.; 15 x $14 \mathrm{~cm}$; blue wrappers; 250 copies.

A BIBLIOGRAPHY OF THE PUBLICATIONS OF THE ROWFANT CLUB-1892-1924, by Arthur H. Clark. Cleveland: The Rowfant Club. 136 p.; $24 \mathrm{~cm}$.; blue cloth-backed boards; 140 copies. 
THE BOOKPLATE ANNUAL FOR 1925, edited by Alfred Fowler. Kansas City: Alfred Fowler. 53 p.; 33 x 25 cm.; blue paper boards; illus.; 500 copies.

DOCTOR SAMUEL JOHNSON AND THE AMERICAN COLONIES, by Charles McCamic. Cleveland: The Rowfant Club. 56 p.; $20 \times 13$ cm.; grey wrappers; 125 copies.

THE [ROWFANT CLUB] YEAR BOOK FOR 1925. ICleveland: The Rowfant Club] 142 p.; 19 x 12 cm; blue cloth-backed boards; slipcased; illus.; 132 copies.

THE WOODCUT ANNUAL FOR 1925, edited by Alfred Fowler. Kansas City: Alfred Fowler. 52 p.; 33 x 25 cm.; orange paper boards; illus.; 600 copies.

\section{6}

GEORGE CROGHAN AND THE WESTWARD MOVEMENT, 17411782, by Albert T. Volwiler. Cleveland: The Arthur H. Clark Co. 370 p.; 23 x 15 cm.; grey wrappers; illus.; 1,000 copies. (Howes V14la.)

REKINDLING CAMP FIRES, by Lewis F. Crawford. Bismark: Capitol Book Co. 324 p.; $23 \times 15$ cm.; $1 / 2$ morocco; illus.; 100 copies. (Adams 262; Graff 912; Howes C872; Rader 959; Smith 2100.)

SHORT READINGS IN MASONIC HISTORY, . . . by J. Hugo Tatsch, rev. ed. 61 p.; 18.5 x 12.5 cm.; blue cloth-backed boards; illus.; 1,000 copies. [First edition of 2,000 copies, June 1926, not seen.]

\section{7}

HUNTING BOOKPLATES IN MEXICO: ]. W. SPENCELEY, by Frederick Starr. [n.p.] Privately printed. 27 p.; 20.5 x 16 cm.; wrappers; illus.; 100 copies.

PREFACES BY LEIGH HUNT, MAINLY TO HIS PERIODICALS, edited by R. Brimley Johnson. Chicago: Walter M. Hill. 150 p.; $20 \times 14$ cm.; red cloth; 500 copies.

1928

LITTLE STORIES OF MASON CITY'S PAST, 1851-1870, by Edith Rule. Mason City: Privately printed. 103 p.; 20 x 14 cm.; percale-print cloth; 300 copies.

MASONIC BOOKPLATES, by J. Hugo Tatsch and Winward Prescott. Cedar Rapids: Masonic Bibliophiles. 149 p.; 28.5 x 21 cm.; blue clothbacked boards; illus.; 102 copies.

SUNSHINE AND GOSSAMER, by Mary L. Baker. Illustrations by Terrell [43] 
Stapp. Chicago: Privately printed. 40 p.; 23 x $16 \mathrm{~cm}$; cloth-backed orange boards; 300 copies.

THE UNITED STATES: A CATALOGUE OF BOOKS RELATING TO THE HISTORY OF ITS VARIOUS STATES, COUNTIES AND CITIES AND TERRITORIES . . . Cleveland: The Arthur H. Clark Co. 411 p.; $23.5 \times 16 \mathrm{~cm}$; green cloth; "245 copies were specially printed on antique laid paper and bound in cloth.”

\section{9}

THE CROWNING YEARS; A BOOK OF VERSE, by Clinton Scollard. Chicago: The Bookfellows. 120 p.; 18 x $13 \mathrm{~cm}$.; grey cloth-backed boards; "fewer than 200 copies."

\section{0}

THE VOICE AT EVE, by Elaine Goodale Eastman. Chicago: The Bookfellows. 122 p.; $18 \times 13$ cm.; brown cloth-backed boards; 225 copies.

\section{2}

GEORGE WASHINGTON, CITIZEN AND FARMER, by Jens Christian Bay [n.p.] Privately printed. 26 p.; $20.5 \mathrm{~cm}$.; grey-blue wrappers; 75 copies.

I SIT AND LOOK OUT, EDITORIALS FROM THE BROOKLYN DAILY TIMES, by Walt Whitman, selected and edited by Emery Holloway and Vernolian Schwartz. New York: Columbia University Press. 175 p.; $23.5 \mathrm{x}$ $16 \mathrm{~cm}$; brown cloth; 1,000 copies.

LETTERS FROM AN OUTSIDER TO AN INSIDER, by Henry Howard Harper. Cedar Rapids: The Torch Press. 124 p. $24 \times 17 \mathrm{~cm}$; light orange paper boards with vellum spine; separately printed insert reads, "One hundred and forty-nine copies of this book have been printed for members of the Bibliophile Society who subscribed to the prior issue."

TRUE TALES OF IOWA, by Edith Rule, and William I. Petersen. Mason City: Yelland \& Hanes. 364 p.; 21 x 15 cm.; mauve cloth. 1,000 copies.

1935

JOYS OF THE TRAIL, by Hamlin Garland. Chicago: The Bookfellows. 46 p.; $23 \times 15$ cm.; green $1 / 2$ cloth and wood-grained boards; 100 copies.

1936

APICIUS: COOKERY AND DINING IN IMPERIAL ROME; A BIBLIOGRAPHY, CRITICAL REVIEW AND TRANSLATION OF THE ANCIENT BOOK KNOWN AS Apicius De Re Coquinaria, now for the first time rendered into English by Joseph Dommers Vehling. . . . Chicago: 
Walter M. Hill. 301 p.; $27.5 \times 20$ cm.; green boards, green cloth spine; illus.; 530 copies.

\section{8}

THE MISSING CHAPTER IN THE LIFE OF ABRAHAM LINCOLN, . . by Bess V. Ehrmann. Pen and ink sketches by Mary Lee Gabbert. Chicago: Walter M. Hill. 150 p.; 24 x $16 \mathrm{~cm}$.; blue cloth; illus.; 1,000 copies.

\section{1}

ROMANTIC MR. DICKENS: A COMEDY-DRAMA IN THREE ACTS, by H. H. and Marguerite Harper. . . . Cedar Rapids: The Torch Press. 118 p.; $20 \times 14 \mathrm{~cm}$.; blue cloth, paper label; illus.; 100 copies. ("A special edition of one hundred copies has been printed for complimentary distribution.")

\section{Significant Americana}

In determining items for inclusion in the "significant Americana" listing, the following bibliographies were checked for Torch Press items:

Adams: Six-Guns \& Saddle Leather: A Bibliography of Books and Pamphlets on Western Outlaws and Gunmen, compiled by Ramon F. Adams, rev. ed. (Norman, 1969).

Ayer: Narratives of Captivity among the Indians of North America: A List of Books and Manuscripts on This Subject in the Edward E. Ayer Collection of the Newberry Library. (Chicago, 1912) and supp. (1928).

Buck: Travel and Description [in Illinois] 1765-1865, Together with A List of County Histories, Atlases, and Biographical Collections..., by Solon Justus Buck (Springfield, 1914).

Cowan: A Bibliography of the History of California, 1510-1930, by Robert Emest Cowan and Robert Granniss Cowan, 2 vols. (San Francisco, 1933).

Dornbusch: Regimental Publications \& Personal Narratives of the Civil War: A Checklist, compiled by C. E. Dormbusch, 2 vols. (New York, 1961-1967).

Graff: A Catalogue of the Everett D. Graff Collection of Western Americana, compiled by Colton Storm (Chicago, 1968).

Howes: U.S.-iana (1650-1950), a Selective Bibliography in Which Are Described 11,620 Uncommon and Significant Books Relating to 
the Continental Portion of the United States, compiled by Wright Howes, rev. ed. (New York, 1962).

Rader: $\quad$ South of Forty from the Mississippi to the Rio Grande: A Bibliography, by Jesse L. Rader (Norman, 1947).

Smith: Pacific Northwest Americana: A Check List of Books and Pamphlets Relating to the History of the Pacific Northwest, by Charles W. Smith, 3rd ed. (Portland, 1950).

The number of Torch Press productions found in the standard Western bibliographies is impressive. Almost half of these items were printed by Torch for the Arthur H. Clark Company of Cleveland between the years 1906 and 1931, and they are a testimony to the editorial genius of $\mathrm{Mr}$. Arthur $\mathrm{H}$. Clark. The remaining half are a tribute to the careful discernment of Luther A. Brewer.

The long, happy, and fruitful association of the Torch Press and the Arthur H. Clark Company was eventually a victim of distance and logistics. Clark's move in 1930 from Cleveland to Glendale, California, took him beyond the necessary range of communication-frequent, exigent, and occasionally frantic-inseparable from the production of printed pages from manuscript material.

The Torch pressmark, contrary to usual practice, appears on only a few of the books issued by Clark. I am consequently very much indebted to Arthur and Robert Clark for information which could be yielded only by their correspondence files, the Torch Press records not having survived. ${ }^{6}$

In an advertising leaf inserted in E. E. Sparks's The English Settlement in Illinois (1906), Luther Brewer announced the Torch Press as a printer of Americana-no idle boast, but a quiet statement of his competence in recognizing significant documents of the western frontier experience, and of his ability to set the pieces in type. The virtual cessation of the Torch Press output of significant Americana in the 1930 s is surely explained only in part by the Clark move to California in 1930. Only three items that weren't in the shop at the time of the Clark removal will be found in the following list of Americana. The same falling off is seen in the listing of limited editions, and it is equally apparent in the Carney and Crawford bibliography. The sig-

6 In addition to invaluable assistance from the Arthur $\mathrm{H}$. Clark Company, I should acknowledge help from at least 50 libraries across the country. I am especially indebted to Ms. Alice N. Loranth, head of the rare book room at the Cleveland Public Library; Harriet Jameson of the University of Michigan; Tom Carney of the Cedar Rapids Public Library; and to the Stewart Library at Coe College. 
nificant work of the Torch Press appears to have been halted mainly by the Depression.

A reading of the sketchy correspondence that Ed Misak of the press deposited with the State Historical Society of Iowa supports this view. One letter in the file, from a Baltimore bookseller, Meredith Janvier, alludes to economic ills with a French charm that must be quoted in full:

I estimated your weight at 165 , and came within 3 lbs. but after your generous adjustment of my hoary balance, I feel utterly incapable of guessing the size of your heart, except to say it is evidently large as your entire body, and yet, through the wonders of nature, is somehow contained inside under your ribs.

This was dated 1935. In another letter, Walter M. Hill, discussing options for printing a Christmas booklet in 1936, concludes with the remark that "I feel I have to cut out any extravagances for the time being and economize." These are personal notes indicating that tight money was choking off fine presswork. But the facts speak for themselves: The Bibliophile Society had an item done at the Torch Press in 1930, then nothing until 1939, when their last issue was printed in Cedar Rapids. The Rowfant Club had their last printing done at Torch in 1925. Walter Hill had only three books printed at the press after 1930. A flurry of printing for Columbia University Press petered out in the 1930s. The last of the Centaur Bookshop bibliographies was printed in 1932, and I have seen a letter from this bookshop apologizing for the balance due on account.

Concomitant with the Depression was the retirement of Luther Brewer in 1929, when Ed Misak assumed the presidency of the Torch Press. Although the quality of all production, and the quantity of significant production, fell away drastically after 1930, to my eye the quality of the presswork remained very high. The decline is apparent in the loss of fine and expensive materials that go into the production of a fine book, and this, I believe, was a result of economic troubles. But the loss of Luther Brewer was undoubtedly keen: the loss of his business sense, his intuitive genius in book design, his editorial acumen.

Certain books of local Iowa interest have been omitted from the following list of Torch Press Americana solely because they were beyond the ken of Wright Howes or Everett Graff or other bibliographers. Some of these items of Iowana are very good books indeed, and it may be that Luther Brewer showed better judgment in printing them than I did in excluding them. My sole reason for omitting "Iowana" is that I did not want any shadow of purely local interest to obscure the most significant work of the press. 
AMANA: THE COMMUNITY OF TRUE INSPIRATION, by Bertha M. H. Shambaugh. Iowa City: State Historical Society of Iowa. 414 p.; 22.5 x $15 \mathrm{~cm}$; green cloth; illus.

DOWN THE CEDAR RIVER. AN ACCOUNT OF A LITTLE VOYAGE FROM VINTON TO CEDAR RAPIDS, WITH MANY LANDINGS ON THE WAY, by Frederick John Lazell. Cedar Rapids: The Torch Press. 8 p.; 24 x 16 cm.; cream wrappers. (Graff 2421.)

1909

MEMOIRS OF GUSTAVE KOERNER, 1809-1896, edited by Thomas J. McCormack. Cedar Rapids: The Torch Press. 2 vols.: 628, 770 p.; 25 x 16 cm.; red ribbed cloth, gilt tops. (Buck 270; Graff 2353; Howes K243.)

THE NAVAJOS, by Oscar H. Lipps. Cedar Rapids: The Torch Press. 136 p.; $20 \times 13.5 \mathrm{~cm}$; grey boards; illus.

OLD TIMES ON THE UPPER MISSISSIPPI; THE RECOLLECTIONS OF A STEAMBOAT PILOT FROM 1854 TO 1863, by George Byron Merrick. Cleveland: The Arthur H. Clark Co. 323 p.; 24 x 16 cm.; blueribbed cloth, gilt top; illus. (Graff 2756; Howes M539.)

REPEAL OF THE MISSOURI COMPROMISE, by P. Orman Ray. Cleveland: The Arthur H. Clark Co. 315 p.; 23.5 x $16 \mathrm{~cm}$; green cloth. (Howes R80.)

THE DAWN OF THE WORLD; MYTHS AND WEIRD TALES TOLD BY THE MEWAN INDIANS OF CALIFORNIA, collected and edited by C. Hart Merriam. 273 p.; 24 x $16 \mathrm{~cm}$; red cloth; colored illus. (Cowan.)

EASTERN KENTUCKY PAPERS; THE FOUNDING OF HARMAN'S STATION, WITH AN ACCOUNT OF THE INDIAN CAPTIVITY OF MRS. JENNIE WILEY AND THE EXPLORATION AND SETTLEMENT OF THE BIG SANDY VALLEY, by William Elsey Connelley. New York: The Torch Press. 177 p.; $24 \times 15.5$ cm.; illus. (Ayer 52.)

JOHN BROWN, LIBERATOR OF KANSAS AND MARTYR OF VIRGINIA, LIFE AND LETTERS, edited by F. B. Sanborn. Fourth edition. Cedar Rapids: The Torch Press. 645 p.; 20 cm.; dark green cloth; illus.

QUANTRILL AND THE BORDER WARS, by William Elsey Connelley. Cedar Rapids: The Torch Press. 542 p.; 24 x 15 cm.; red cloth; illus. (Adams 237; Graff 850; Howes C689; Rader 894.)

1911

AUTOBIOGRAPHY OF CHARLES CLINTON NOURSE . . . INCI- 
DENTS OF MORE THAN FIFTY YEARS' PRACTICE AT THE BAR IN THE STATE OF IOIVA. Cedar Rapids: Privately printed. 235 p.; 24 x 16 cm.; blue cloth; illus. (Graff 3046.)

THE BATTLE OF SHILOH, by Joseph W. Rich. Iowa City: State Historical Society of Iowa. 134 p.; $22.5 \times 15 \mathrm{~cm}$; red cloth; illus. (Dornbusch I: Ia 150.)

THE INDIAN TRIBES OF THE UPPER MISSISSIPPI VALLEY AND REGION OF TIHE GREAT LAKES, . . . edited by Emma Helen Blair. Cleveland: The Arthur H. Clark Co. 1911-12. 2 vols.: 372, 412 p.; 24 x 16 cm.; red cloth; illus. (Howes B498.)

THE IOWA. A REPRINT FROM The Indian Record, AS ORIGINALLY PUBLISHED AND EDITED BY THOMAS FOSTER, with introduction, and elucidations through the text by William Harvey Miner. Cedar Rapids: The Torch Press. 100 p.; 20.5 x 14 cm.; gray boards; illus.

THE LEADING FACTS OF NEW MEXICAN HISTORY, by Ralph Emerson Twitchell. Cedar Rapids: The Torch Press, 1911-12. 2 vols.: 506, 631 p.; illus. (Adams 1021; Howes T443; Rader 3167.)

LOUISIANA UNDER THE RULE OF SPAIN, FRANCE, AND THE UNITED STATES 1785-1807, . . . edited by James Alexander Robertson. Cleveland: The Arthur H. Clark Co. 2 vols.: 376, 391 p.; 24 x 16 cm.; red cloth; illus. (Howes R354.)

RAFINESQUE: A SKETCH OF HIS LIFE WITH BIBLIOGRAPHY, by T. J. Fitzpatrick. Des Moines: The Historical Department of Iowa. 241 p;; $24 \times 16 \mathrm{~cm}$;; cloth-backed boards; illus.

REMINISCENCES OF THE CIVIL WAR, BY EMMA CASSANDRA MACON AND REUBEN CONWAY MACON, ADJUTANT, THIRTEENTH VIRGINIA INFANTRY, EWELL'S DIVISION, STONEWALL JACKSON'S CORPS, C.S.A. [n.p.] Privately printed. 158 p.; 23 x 15 cm; olive-green boards; illus.

TIMOTHY FLINT: PIONEER, MISSIONARY, AUTHOR, EDITOR, 1780-1840, . . . by John Ervin Kirkpatrick. Cleveland: The Arthur H. Clark Co. 331 p.; 23.5 x 15.5 cm.; red cloth; illus.

1912

THE FIRST EXPLORATIONS OF THE TRANS-ALLEGHENY REGION BY THE VIRGINIANS, 1650-1674, by Clarence Walworth Alvord and Lee Bidgood. Cleveland: The Arthur H. Clark Co. 275 p.; $23.5 \times 16$ cm.; blue cloth; illus. (Howes A194.)

1914

ATHANASE DE MEZIERES AND THE LOUISIANA-TEXAS FRONTIER, 1768-1780, . . . edited and annotated by Herbert E. Bolton. Cleve- 
land: The Arthur H. Clark Co. 2 vols.: 315, 392 p.; red cloth; folding map. (Howes B584.)

A CONCISE HISTORY OF NEW MEXICO, by L. Bradford Prince. 2nd ed. Cedar Rapids: The Torch Press. 279 p.; 21.5 x $15 \mathrm{~cm}$; red cloth, illus.

RUSSIAN EXPANSION ON THE PACIFIC, 1641-1850, ... by F. A. Golder. Cleveland: The Arthur H. Clark Co. 368 p.; 24 x 16 cm.; red cloth; illus. (Howes G223; Smith 3636.)

THE SPANISH ARCHIVES OF NEW MEXICO, . . . by Ralph Emerson Twitchell. Cedar Rapids: The Torch Press. 2 vols.: 525, 683 p.; 24 x 16 cm.; red cloth; illus. (Howes T445.)

1915

THE AMERICAN INDIAN AS SLAVEHOLDER AND SECESSIONIST; AN OMITTED CHAPTER IN THE DIPLOMATIC HISTORY OF THE SOUTHERN CONFEDERACY, by Annie Heloise Abel. Cleveland: The Arthur H. Clark Co. 394 p.; 24 x 16 cm.; red cloth; illus. (Howes A9.)

THE HOPI INDIANS, by Walter Hough. Cedar Rapids: The Torch Press. 265 p.; 21 × 14 cm.; brown cloth; illus.

THE INDIANS OF GREATER NEW YORK, by Alanson Skinner. Cedar Rapids: The Torch Press. 150 p.; 20.5 x 14.5 cm.; grey boards; map.

SPANISH MISSION CHURCHES OF NEW MEXICO, by L. Bradford Prince. 373 p.; $20 \times 14$ cm.; cloth; illus. (Howes P613.)

1916

THE MISSISSIPPI VALLEY IN BRITISH POLITICS; A STUDY OF THE TRADE, LAND SPECULATION, AND EXPERIMENTS IN IMPERIALISM CULMINATING IN THE AMERICAN REVOLUTION, by Clarence Walworth Alvord. Cleveland: The Arthur H. Clark Co. 2 vols.: 358, 396 p.; 23.5 x 15.5 cm.; blue cloth; maps. (Howes A195.)

THIRD PARTY MOVEMENTS SINCE THE CIVIL WAR, WITH SPECIAL REFERENCE TO IOWA: A STUDY IN SOCIAL POLITICS, by Fred E. Haynes. Iowa City: State Historical Society of Iowa. 564 p.; $22.5 \mathrm{x}$ $15 \mathrm{~cm}$; red cloth. (Howes H348.)

1917

THE ASHLEY-SMITH EXPLORATION AND DISCOVERY OF A CENTRAL ROUTE TO THE PACIFIC, 1822-1829, edited by Harrison C. Dale. Cleveland: The Arthur H. Clark Co. 352 p.; $25 \times 16.5$ cm.; red cloth; illus. (Howes D21; Smith 2224.) 
OLD FORT SNELLING: 1819-1858, by Marcus L. Hansen. Iowa City: The State Historical Society of Iowa. 270 p.; 22.5 x $15.5 \mathrm{~cm}$.; red cloth; illus.

THE SPIRIT LAKE MASSACRE, by Thomas Teakle. Iowa City: The State Historical Society of Iowa. 336 p.; $22.5 \times 15 \mathrm{~cm}$; red cloth. (Ayer sup. 124.)

1919

THE AMERICAN INDIAN AS PARTICIPANT IN THE CIVIL WAR, by Annie Heloise Abel. Cleveland: The Arthur H. Clark Co. 403 p.; 24 x 16 cm.; red cloth; illus. (Dornbusch III, 285; Howes A9.)

1920

THE ARIKARA NARRATIVE OF THE CAMPAIGN AGAINST THE HOSTILE DAKOTAS, JUNE, 1876, edited by O. G. Libby. Bismarck: North Dakota Historical Collections [vol. 6]. 276 p.; $24 \times 16$ cm.; green cloth; illus.

1921

A HISTORY OF THE PEOPLE OF IOWA, by Cyrenus Cole. Cedar Rapids: The Torch Press. 572 p.; 24 x 16 cm.; blue cloth; illus. (Howes C566.)

1922

THE BOZEMAN TRAIL: HISTORICAL ACCOUNTS OF THE BLAZING OF THE OVERLAND ROUTES INTO THE NORTHWEST, AND THE FIGHTS WITH RED CLOUD'S WARRIORS, by Grace Raymond Hebard and E. A. Brinninstool. Cleveland: The Arthur H. Clark Co. 2 vols.: 346, 306 p.; $23.5 \times 16 \mathrm{~cm}$.; red cloth; folding maps; illus. (Howes H382; Smith 4288.)

1924

EIGHT MONTHS IN ILLINOIS, WITH INFORMATION TO IMMIGRANTS, by William Oliver. Chicago: Walter M. Hill. [Reprint of 1843 edition.] 260 p.; $20.5 \times 14$ cm.; blue cloth. (Buck 375; Howes 071; Graff 3093.)

HISTORY OF THE LOST STATE OF FRANKLIN, by Samuel Cole Williams. Johnson City, Tenn.: The Watanga Press. 371 p.; $23 \times 15.5 \mathrm{~cm}$.; blue cloth. (Howes W484.)

THE INSIDE PASSAGE TO ALASKA, 1792-1920, by William W. Wool- 
len. Cleveland: The Arthur H. Clark Co. 2 vols.: 342,318 p.; $24.5 \times 17$ cm.; green cloth; illus. (Smith 11208.)

THE OUTLAWS OF CAVE-IN-ROCK; HISTORICAL ACCOUNTS OF THE FAMOUS HIGHWAYMEN AND RIVER PIRATES WHO OPERATED IN PIONEER DAYS UPON THE OHIO AND MISSISSIPPI RIVERS AND OVER THE OLD NATCHEZ TRACE, by Otto A. Rothert. Cleveland: The Arthur H. Clark Co. 364 p.; 24 x 16 cm.; red cloth; illus. (Adams 1908; Howes R466.)

ADOBE DAYS, A BOOK OF CALIFORNIA MEMORIES, by Sarah BixbySmith. Cedar Rapids: The Torch Press. 217 p.; $18.5 \mathrm{~cm}$; grey cloth; illus. (Cowan.) [A revised edition was published in 1926.]

THE AMERICAN INDIAN UNDER RECONSTRUCTION, by Annie Heloise Abel. Cleveland: The Arthur H. Clark Co. 419 p.; 24 x 16 cm.; red cloth. (Howes A9.)

FORTY YEARS ON THE FRONTIER AS SEEN IN THE JOURNALS AND REMINISCENCES OF GRANVILLE STUART, . . . edited by Paul C. Phillips. Cleveland: The Arthur H. Clark Co. 2 vols.: 272, 265 p.; 23.5 x $16 \mathrm{~cm}$; blue cloth; illus. (Howes S1096; Smith 9974.)

\section{6}

BADLANDS AND BRONCHO TRAILS, by Lewis F. Crawford, 2nd ed. Bismarck: Capitol Book Co. 99 p.; 20 x 12.5 cm.; red cloth; illus.

THE ELY AND WEARE FAMILIES, PIONEERS OF MICHIGAN AND IOWA, by Elisha D. Ely. Cedar Rapids: Privately printed. 93 p.; 21 x 16 cm.; red cloth; illus. (Graff 1244.)

THE PRAIRIE AND THE MAKING OF MIDDLE AMERICA: FOUR CENTURIES OF DESCRIPTION, by Dorothy Ame Dondore. Cedar Rapids: The Torch Press. 472 p.; $20 \times 13.5 \mathrm{~cm}$; red cloth; illus.

THE OVERLAND MAIL, PROMOTER OF SETTLEMENT, PRECURSOR OF RAILROADS 1849-1869, by Leroy R. Hafen. Cleveland: The Arthur H. Clark Co. 361 p.; 24 x 16 cm.; green cloth; illus. (Cowan; Howes H11.)

PIONEER DAYS IN THE EARLY SOUTHWEST, by Grant Foreman. Cleveland: The Arthur H. Clark Co. 349 p.; 24 x 16 cm.; red cloth; illus. (Howes F260.)

1928

THE ORGANIZATION AND ADMINISTRATION OF THE UNION ARMY, 1861-1865, by Fred Albert Shannon. Cleveland: The Arthur H. 
Clark Co. 2 vols.: 323, 348 p.; 24 x 16 cm.; blue cloth; illus. (Dornsbusch III, 814; Howes S327.)

CHRISTOPHER C. ANDREWS, PIONEER IN FORESTRY CONSERVATION IN THE UNITED STATES . . RECOLLECTIONS: 1829-1922, edited by Alice E. Andrews. Cleveland: The Arthur H. Clark Co. 327 p.; $24 \times 16 \mathrm{~cm}$.; red cloth; illus.

THE SOUTHWESTERN FRONTIER, 1865-1881, . . . by Carl Coke Rister. Cleveland: The Arthur H. Clark Co. 336 p.; 24 × 16 cm.; brown cloth; illus. (Howes R318.)

TWO GREAT SCOUTS AND THEIR PAWNEE BATTALION; THE EXPERIENCES OF FRANK I. NORTH AND LUTHER H. NORTH, . . . by George Bird Grinnell. Cleveland: The Arthur H. Clark Co. 299 p.; 24 x $16 \mathrm{~cm}$; red cloth; illus. (Smith 3901.)

1929

COVERED WAGON DAYS. A JOURNEY ACROSS THE PLAINS IN THE SIXTIES, AND PIONEER DAYS IN THE NORTHWEST, by Albert Jerome Dickson. Cleveland: The Arthur H. Clark Co. 287 p.; 24 x 15.5 cm.; blue cloth; illus. (Adams 591; Graff 1082; Smith 2445.)

THE FUR-TRADE AND EARLY WESTERN EXPLORATION, by Clarence A. Vandiveer. Cleveland: The Arthur H. Clark Co. 316 p.; $24 \times 16$ cm.; green cloth; illus. (Smith 10511.)

JUAN MARIA DE SALVATIERRA OF THE COMPANY OF JESUS, MISSIONARY IN THE PROVINCE OF NEW SPAIN, AND APOSTOLIC CONQUEROR OF THE CALIFORNIAS, by Miguel Venegas. Translated into English, edited and annotated by Marguerite Eyer Wilbur. 350 p.; $24 \mathrm{x}$ $16 \mathrm{~cm}$; red cloth; illus. (Cowan; reprint of Howes V68.)

MISSIONS AND PUEBLOS OF THE OLD SOUTHWEST . . WITH SOME ACCOUNT OF THE INDIAN TRIBES AND THEIR DANCES; AND OF THE PENITENTES, by Earle R. Forrest. Cleveland: The Arthur H. Clark Co. 386 p.; 24 x 16 cm.; blue cloth; illus.

A RAFT PILOT'S LOG: A HISTORY OF THE GREAT RAFTING INDUSTRY ON THE UPPER MISSISSIPPI, 1840-1915, by Walter A. Blair. Cleveland: The Arthur H. Clark Co. 328 p.; 23.5 x 16 cm.; blue cloth; illus.

JOURNAL OF A VOYAGE INTO THE SOUTH SEAS IN 1684 AND THE FOLLOWING YEARS WITH THE FILIBUSTERS, by Raveneau de Lussan, Buccaneer of the Spanish Main and Early French Filibuster of the Pacific, translated and edited by Marguerite Eyer Wilbur. Cleveland: The Arthur H. Clark Co. 303 p.; 24 x 16 cm.; red cloth; illus. 
STAGECOACH AND TAVERN TALES OF THE OLD NORTHWEST, by Harry Ellsworth Cole, edited by Louise Phelps Kellogg. Cleveland: The Arthur H. Clark Co. 376 p.; $24 \times 16 \mathrm{~cm}$.; blue cloth; illus.

A TRAVELER IN INDIAN TERRITORY; THE JOURNAL OF ETHAN ALLEN HITCHCOCK, LATE MAJOR-GENERAL IN THE UNITED STATES ARMY, edited and annotated by Grant Foreman. Cedar Rapids: The Torch Press. 270 p.; 23.5 x $16 \mathrm{~cm}$.; red cloth; illus. (Howes H537.)

WASHAKIE; AN ACCOUNT OF INDIAN RESISTANCE OF THE COV. ERED WAGON AND UNION PACIFIC RAILROAD INVASIONS OF THEIR TERRITORY, by Grace Raymond Hebard. Cleveland: The Arthur H. Clark Co. 338 p.; 24 x 16 cm.; red cloth; illus. (Howes H384; Smith 4296.)

\section{1}

ADVENTURES IN THE SANTA FE TRADE, 1844-1847, by James Josiah Webb, edited by Ralph P. Bieber. Glendale, Calif.: The Arthur H. Clark Co. 301 p.; $23.5 \times 16$ cm.; red cloth; illus.

1932

A HISTORY OF TRANSPORTATION IN THE OHIO VALLEY, by Charles H. Ambler. Cleveland: The Arthur H. Clark Co. 465 p.; 24.5 x $15.5 \mathrm{~cm}$; dark blue buckram; illus.

1937

THE DISCOVERY AND EXPLOITATION OF THE MINNESOTA IRON LANDS, by Fremont P. Wirth. Cedar Rapids: The Torch Press. 247 p.; $19.5 \times 13.5 \mathrm{~cm}$.; blue cloth; illus.

STEAMBOATING ON THE UPPER MISSISSIPPI, THE WATERWAY TO IOWA: SOME RIVER HISTORY, by Wm. J. Petersen. Iowa City: The State Historical Society of Iowa. 576 p.; 23.5 x $16 \mathrm{~cm}$.; green cloth. (Howes P263.)

1956

THE INDIAN WARS OF MINNESOTA, by Louis H. Roddis. Cedar Rapids: The Torch Press. 312 p.; $23.5 \times 16 \mathrm{~cm}$; red cloth; illus. 


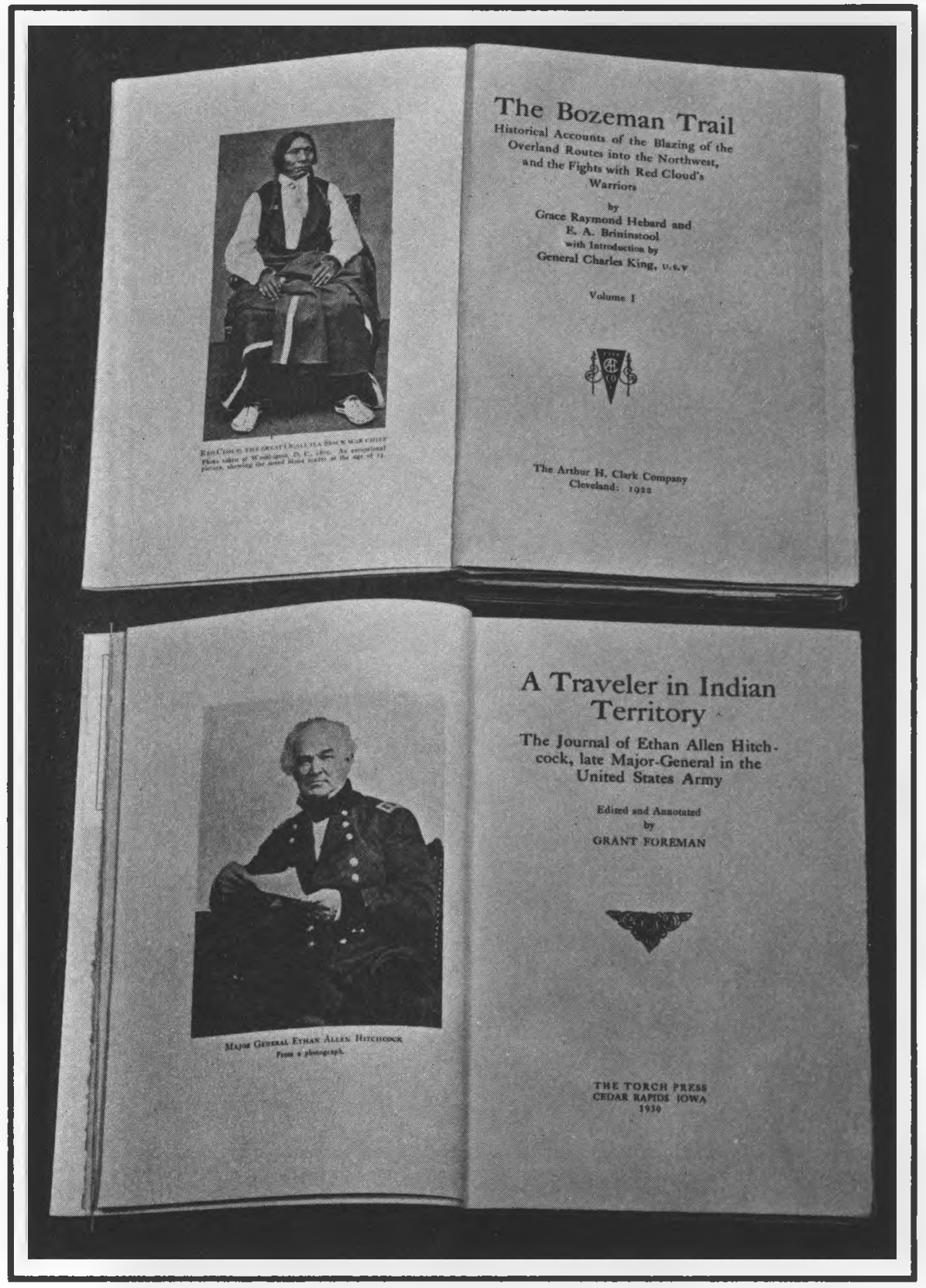

Representative of the many significant volumes of Americana printed by the Torch Press of Cedar Rapids, Iowa, are The Bozeman Trail (1922) and A Traveler in Indian Territory (1930). 